Gut, 1982, 23, 239-242

\title{
Bedtime cimetidine maintenance treatment: optimum dose and effect on subsequent natural history of duodenal ulcer*
}

\author{
W. J F FITZPATRICK, W S BLACKWOOD, AND T C NORTHFIELD \\ From the Norman Tanner Gastroenterology Unit, St. James's Hospital, and Department of Medicine, \\ St. George's Hospital Medical School, London
}

SUMmaRY Sixty patients, whose duodenal ulcers had healed endoscopically after six weeks of treatment with cimetidine $1 \mathrm{~g} /$ day in divided doses, were treated with maintenance cimetidine 800 $\mathrm{mg}$ at bedtime for six months. Eighteen relapsed endoscopically (30\%). Of the 42 still in remission, 36 then completed a six month double-blind comparison of bedtime cimetidine $400 \mathrm{mg}$ and placebo. Twelve of the $19(63 \%)$ cimetidine-treated patients and 10 of $17(59 \%)$ placebo-treated patients relapsed within six weeks (NS). This high relapse rate on cimetidine contrasts with our earlier trial, in which the six week relapse rate was only two out of $21(10 \%)$ on bedtime cimetidine $800 \mathrm{mg}$ and 16 out of $24(66 \%)$ on placebo $(P<0.0005)$. Apart from the difference in the dose of cimetidine, both our trials used the same experimental protocol during the double-blind part of the trial. In the earlier trial, however, there was no period of pretreatment with maintenance cimetidine as in the present trial. The pattern of placebo relapse was similar in both trials. We conclude that bedtime cimetidine maintenance treatment does not alter the long-term natural history of duodenal ulcer once it has been withdrawn; and that either tolerance to cimetidine develops during long-term maintenance treatment, or that bedtime cimetidine maintenance treatment in the conventional dose of $400 \mathrm{mg}$ is not as effective as $800 \mathrm{mg}$ in prevention of endoscopic relapse, although it does reduce symptoms.

The histamine $\mathrm{H}_{2}$ receptor antagonist cimetidine promotes duodenal ulcer healing. ${ }^{1-3}$ Maintenance therapy reduces the relapse rate in patients receiving the recommended dose of $400 \mathrm{mg}$ at bedtime, but clinical trials have been mainly based on symtomatic relapse, with subsequent endoscopic confirmation. Additional endoscopies have been carried out at regular intervals in only a minority of trials, ${ }^{4-6}$ and even then at infrequent intervals, usually once every six months ${ }^{4-6}$ which may not be adequate to provide reliable figures for asymptomatic relapse. Thus, it is not clear whether the main effect of cimetidine maintenance treatment $400 \mathrm{mg}$ at bedtime is due to prevention of duodenal ulcer recurrence, or to prevention of symptoms (antacid effect) once the ulcer has recurred. If the latter were the main effect, this

* This study was presented at the annual meeting of the British Society of Gastroenterology, 1979.

$\dagger$ Present address: Merrimack Medical Park, Merrimack, New Hampshire 03054, USA.

Received for publication 10 September 1981 might account for the finding that there is a progressive increase in symptomatic relapse rate with time, reported as $2 \%$ per month in combined figures from many centres.?

Duodenal ulcer is a self-limiting disease, with a strong tendency to go into spontaneous remission after a variable number of years. ${ }^{8}$ Thus, no relapse might follow a period of maintenance treatment in those due to go into spontaneous remission during this time. On the other hand, spontaneous remission might be due to some protective mechanism, suppressed by maintenance treatment with cimetidine, in which case cessation of treatment might be followed by an increased relapse rate or 'rebound phenomenon'. The latter possibility is raised by the many anecdotal reports of perforated duodenal ulcer, acute gastrointestinal bleeding, and severe ulcer pain shortly after stopping cimetidine; by the finding that the relapse rate is higher in patients whose duodenal ulcers have healed on cimetidine treatment than in those who have healed on placebo; 9 and by the report that relapse is more common after stopping treatment 
with cimetidine than after stopping treatment with tripotassium dicitrato bismuthate. ${ }^{10}$ On the other hand, several studies ${ }^{11-13}$ have emphasised the frequency with which the symptoms of duodenal ulcer recur after stopping cimetidine maintenance treatment. In some, ${ }^{12} 13$ but not all, ${ }^{11}$ of these reports symptomatic relapse has been confirmed by subsequent endoscopy. In none of these studies have endoscopies, the only truly objective method of studying the effect of cimetidine maintenance treatment on the subsequent natural history of duodenal ulcer, been carried out at regular intervals in asymptomatic patients.

In the current study, endoscopy was carried out at regular intervals in order to determine (1) whether bedtime cimetidine maintenance treatment in the currently recommended dose of $400 \mathrm{mg}$ reduces the endoscopic relapse rate of duodenal ulcer by comparison with placebo. The design of this study was identical with that of our previous double-blind comparison of bedtime cimetidine $800 \mathrm{mg}$ with placebo: ${ }^{14}(2)$ whether six months' maintenance treatment with cimetidine alters the subsequent natural history of duodenal ulcer, as assessed by regular endoscopies after substitution of placebo maintenance treatment on a double-blind basis.

\section{Methods}

\section{PATIENTS}

All the patients had active duodenal ulceration confirmed on endoscopy. They were treated with cimetidine $1 \mathrm{~g}$ daily in divided doses for six weeks, then within one week of endoscopic confirmation of ulcer healing (defined as complete disappearance of all breaks in mucosal surface, however small or superficial) they were started on cimetidine $800 \mathrm{mg}$ at bedtime. After six months' open treatment repeat endoscopy was carried out. Patients having no endoscopic relapse of their duodenal ulcer at this stage were then randomly allocated to bedtime cimetidine in a lower dose of $400 \mathrm{mg}$ or to placebo. Repeat endoscopy was carried out at six, 12, and 24 weeks after randomisation. In our earlier study, ${ }^{14} \mathrm{a}$ double-blind comparison was made between placebo and cimetidine $800 \mathrm{mg}$ at bedtime with repeat endoscopies carried out at the same time intervals. In both trials, endoscopic relapse was defined as reappearance of any break in the continuity of the duodenal mucosa however small. Recurrence of ulcer pain was recorded on diary cards.

The $\chi^{2}$ test (with correction for small numbers) was used to compare the frequency of ulcer relapse. The Wilcoxon rank sum test was used to compare the number of days and nights of pain and antacid consumption on placebo and cimetidine.

\section{Results}

\section{ENDOSCOPIC RELAPSE RATE}

In the open part of our trial, 60 patients received cimetidine in a dose of $800 \mathrm{mg}$ at bedtime for six months. Repeat endoscopy at six months showed that 18 of the 60 patients had relapsed $(30 \%)$. This is a similar relapse rate $(24 \%)$ to that obtained in our previous trial when five out of 21 relapsed on the same dose of cimetidine, ${ }^{14}$ thus confirming the consistency of our endoscopic criteria.

After the open part of the trial, 40 of 42 patients still in endoscopic remission entered the double-blind section with either cimetidine $400 \mathrm{mg}$ or placebo at bedtime. Four failed to complete the six month trial because of the repeated endoscopies involved. Nineteen cimetidine-treated patients and 17 placebo-treated patients completed the trial with endoscopic relapse occurring in 14 and 11 patients respectively (NS). The results for the trial are shown in the Table, which gives the cumulative relapse rate at six, 12 , and 24 weeks after randomisation and compares these with our previous study. In contrast with our first study, bedtime cimetidine in the lower dose of $\mathbf{4 0 0} \mathrm{mg}$ did not reduce the endoscopic relapse rate significantly; whereas the placebo relapse rates in both trials were similar. This difference in the cimetidine results between our two trials was statistically significant at six weeks $(\mathrm{P}<0.001)$, and was maintained throughout the six months' trial.

Table Cumulative endoscopic relapse rates (\%)

\begin{tabular}{|c|c|c|c|c|c|c|c|c|c|}
\hline & \multirow[b]{3}{*}{$(m g)$} & \multicolumn{6}{|c|}{ Weeks after randomisation } & \multirow[t]{3}{*}{ Total } & \multirow[t]{3}{*}{$\mathbf{P}$} \\
\hline & & \multicolumn{2}{|l|}{$\overline{6}$} & \multicolumn{2}{|l|}{12} & \multicolumn{2}{|l|}{24} & & \\
\hline & & (no.) & $(\%)$ & (no.) & $(\%)$ & (no.) & $(\%)$ & & \\
\hline $\begin{array}{l}\text { Present trial* } \\
\text { Cimetidine } \\
\text { Placebo }\end{array}$ & 400 & $\begin{array}{l}12 \\
10\end{array}$ & $\begin{array}{l}63 \\
59\end{array}$ & $\begin{array}{l}13 \\
11\end{array}$ & $\begin{array}{l}68 \\
65\end{array}$ & $\begin{array}{l}14 \\
11\end{array}$ & $\begin{array}{l}74 \\
65\end{array}$ & $\begin{array}{l}19 \\
17\end{array}$ & NS \\
\hline $\begin{array}{l}\text { Cimetidine } \\
\text { Placebo }\end{array}$ & 800 & $\begin{array}{r}2 \\
16\end{array}$ & $\begin{array}{l}10 \\
66\end{array}$ & 21 & $\begin{array}{l}19 \\
87\end{array}$ & $\begin{array}{r}5 \\
21\end{array}$ & $\begin{array}{l}24 \\
87\end{array}$ & $\begin{array}{l}21 \\
24\end{array}$ & $<0.0005$ \\
\hline
\end{tabular}

* After six months' maintenance treatment with cimetidine $800 \mathrm{mg}$ at bedtime.

+ No previous maintenance treatment. 


\section{COMPARISON OF TWO TRIALS FOR PLACEBO} RELAPSE RATES

The Figure shows the cumulative relapse rates on placebo during the double-blind part of both our present and previous trials. To aid the comparison, the cumulative relapse rate in the present trial includes relapses that occurred during the initial open part of the trial during treatment with cimetidine $800 \mathrm{mg}$ at bedtime, so that the relapse rates are different from those quoted in the Table, in which no account is taken of relapse rates in the first six months. In those patients who had received cimetidine $800 \mathrm{mg}$ maintenance treatment at bedtime for six months, the cumulative relapse rate was $72 \%$ at six weeks and $76 \%$ at 12 and 24 weeks. In our previous study, in patients with no previous maintenance treatment, the cumulative relapse rates were $66 \%$ at six weeks and $87 \%$ at 12 and 24 weeks (NS). denal ulcer once cimetidine is stopped. Endoscopy provides the only objective method of assessing relapse rate, and in both studies it was carried out on a double-blind basis. The present findings concur with those ${ }^{11-13}$ based on symptomatic relapse rate in confirming the widespread clinical impression that, once cimetidine maintenance treatment is stopped, then the underlying natural history of the duodenal ulcer reasserts itself; but they do not provide any evidence that the risk of relapse is increased by cimetidine treatment.

Our failure to find any significant reduction in endoscopic relapse rate during maintenance treatment in the conventional dose of $400 \mathrm{mg}$ at bedtime contrasts with our earlier findings using the higher dose of $800 \mathrm{mg}$ at bedtime, despite the similar placebo results in both trials. It also contrasts with other reported trials ${ }^{5-7} 9$ using $400 \mathrm{mg}$ at bedtime, but these other trials have

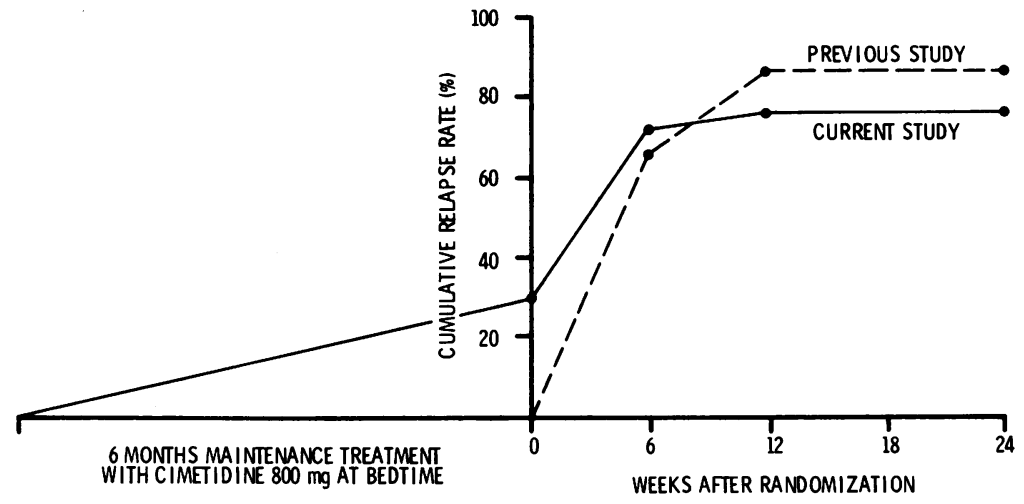

Figure Cumulative endoscopic relapse rates on placebo during previous and current studies

SYMPTOMS

In the cimetidine-treated group the average number of days of pain per patient per week was $1 \cdot 0 \pm 0.2$ over the first six weeks, compared with $2 \cdot 0 \pm 0.1$ per patient per week in the placebo group $(P>0.005)$. There was no significant difference in night time pain and antacid consumption between the two groups. Seven of 11 placebo-treated patients who relapsed endoscopically during the trial but only four of the 14 cimetidinetreated patients had symptoms severe enough to require withdrawal from the trial.

\section{Discussion}

Our findings show that the pattern of endoscopic relapse on placebo after six months' bedtime cimetidine in a dose of $800 \mathrm{mg}$ is similar to that obtained after only six weeks' treatment with cimetidine (Figure). This clearly demonstrates that maintenance treatment with cimetidine given at bedtime for a period of six months does not alter the subsequent natural history of duo- been mainly based on symptomatic relapse rates, subsequently confirmed endoscopically. Furthermore, we found a significant reduction in the overall frequency of daytime pain in the cimetidine-treated patients compared with the placebo-treated patients, despite the absence of any reduction in the endoscopic relapse rate in those treated with cimetidine $400 \mathrm{mg}$ at bedtime. These findings raise the possibility that the reported effect of cimetidine $400 \mathrm{mg}$ at bedtime in reducing ulcer relapse in other trials is mainly an antacid effect, whereas the effect of cimetidine $800 \mathrm{mg}$ at bedtime is due to a real reduction in ulcer relapse rate.

A double-blind comparison between 400 and $800 \mathrm{mg}$ cimetidine given at bedtime is needed in the same group of patients before it can be concluded that there is a definite difference in the endoscopic relapse rate. If no significant difference were found, this would suggest that the reduced efficacy of cimetidine $400 \mathrm{mg}$ in the present study is due to some form of tolerance to cimetidine developing during the six months' pretreatment at the higher dose. 
If future trials confirm that the higher dose of $800 \mathrm{mg}$ at bedtime is more effective in preventing endoscopic relapse, what is the explanation? We have previously reported that doses of $400 \mathrm{mg}$ and $800 \mathrm{mg}$ cimetidine at bedtime inhibit nocturnal acid secretion to the same degree. ${ }^{15}$ On the other hand, there was a difference between the doses in terms of intragastric $\mathrm{pH}$, the higher dose maintaining intragastric $\mathrm{pH}$ close to neutrality throughout the night, whereas the intragastric $\mathrm{pH}$ escaped from control on the lower dose of $400 \mathrm{mg}$ during the latter part of the night and fell to an average value of approximately three, possibly due to a fall in blood cimetidine levels. ${ }^{16}$ Thus, duodenal ulcer relapse may depend on the $\mathrm{pH}$ of the fluid entering the duodenal bulb rather than on the total amount of acid secreted by the stomach during the night.

\section{References}

1 Bodemar G, Walan A. Cimetidine in the treatment of active duodenal and prepyloric ulcers. Lancet 1976; 2:161-4.

2 Blackwood WS, Maudgal DP, Pickard RG, Lawrence D, Northfield TC. Cimetidine in duodenal ulcer. Lancet 1976; 2:174-6.

3 Gray GR, McKenzie I, Smith IS, Crean GP, Gillespie G. Oral cimetidine in severe duodenal ulceration. Lancet 1977; 1:4-7.

4 Gray GR, Smith IS, Mackenzie I, Gillespie G. Long term cimetidine in the management of severe duodenal ulcer dyspepsia. Gastroenterology 1978; 74:397-401.

5 Venables CW, Stephen JG, Blair EL, Reed RD, Saunders JD. Cimetidine in the treatment of duodenal ulceration and the relationship of this therapy to surgical management. Westminster Hospital Symposium 1978; 13-30.

6 Petrillo E, Grossi E, Prada A, Bianchi Porro G. Cimetidine in the long term maintenance treatment of duodenal ulcer. In: Luchelli PE, ed. Cimetidina, farmacologia e clinica. Taormina Symposium 1977; 241-7.

7 Burland WL, Hawkins BW, Beresford J. Cimetidine treatment for the prevention of recurrence of duodenal ulcer: an international collaborative study. Postgrad Med $J$ 1980; 56:173-6.

8 Fry J. Peptic ulcer: a profile. Br Med J 1974; 2:809-12.

9 Burland WL. Treatment of chronic duodenal ulcer with cimetidine. In: Truelove S, ed. Oxford: Blackwell Scientific Publications, 1978; 327-43.

10 Martin DF, Hollanders D, May SJ, Ravenscroft MM, Tweedle DEF, Miller JP. Duodenal ulcer recurrence afterhealing with cimetidine or tripotassium dicitrato bismuthate (DeNol). Gut 1980; 21:920-1.

11 Gudmond-Hфyer E, Binger-Jensen K, Krag E, RaskMadsen J, Rahbek I. Prophylactic effect of cimetidine in duodenal ulcer disease. Br Med J 1978; 1:1095-7.

12 Dronfield MW, Batchelor AJ, Larkworthy W, Langman MJS. Controlled trial of maintenance cimetidine treatment in healed doudenal ulcer: short and long-term effects. Gut 1979; 20:526-30.

13 Korman MG, Hetzel DJ, Hansky J, Shearman DJC, Don G. Relapse rate of duodenal ulcer after cessation of longterm cimetidine treatment. Dig Dis Sci 1980; 25:88-91.

14 Blackwood WS, Maudgal DP, Northfield TC. Prevention by bedtime cimetidine of duodenal-ulcer relapse. Lancet 1978; 1:626-7.

15 Blackwood WS, Northfield TC. Nocturnal gastric acid secretion: effect of cimetidine and interaction with anticholinergics. In: Burland WL, Simkins MA, eds. Proceedings of the 2nd international symposium on histamine $\mathrm{H}_{2}$-receptor antagonists. Amsterdam: Excerpta Medica 1977: 124-30.

16 Northfield TC, Blackwood WS, Fitzpatrick WJF. Bedtime cimetidine: optimal dose, effect on relapse rate and subsequent natural history of duodenal ulcers. In: Proceedings of the 2nd National Symposium on cimetidine, Brussels. Amsterdam: Excerpta Medica, 1980: 140-7. 